\section{Pengaruh Loan To Deposit Ratio, Capital Adequacy Ratio, Dan Non Performing Loan Terhadap Profitabilitas Perbankan Yang Terdaftar Di Bursa Efek Indonesia (BEI)}

\author{
Fanesha, Nusa Muktiadji dan Ganjar Hendrian \\ ${ }^{123}$ Institut Bisnis dan Informatika Kesatuan Bogor \\ Email :
}

\section{ABSTRACT}

This study aims to determine how the influence of Loan to Deposit Ratio, Capital Adequacy Ratio and Non Performing Loans on Banking Profitability Listed on the Indonesia Stock Exchange (IDX) that occurs at PT Bank Central Asia Tbk, PT Bank Rakyat Indonesia (Persero) Tbk, PT Bank Mandiri (Persero) Tbk, PT Bank CIMB Niaga Tbk, PT Bank Negara Indonesia (Persero) Tbk, PT Bank Tabungan Negara (Persero) in 2014-2018.

The data used in this study are quantitative data with secondary data sources derived from the financial statements of each bank. This research uses descriptive statistical analysis methods, inference analysis, classic assumption test, multiple linear analysis and coefficient of determination. Regression analysis is used to find out how the influence of independent variables on the dependent variable with a significance value of 5 percent. While the determination coefficient analysis is used to determine the relationship between the independent variable and the dependent variable.

From the partial hypothesis test (T Test) that has been done by the author, it is obtained that the Loan to Deposit Ratio affects Return On Assets, Capital Adequacy Ratio has no effect on Return On Assets and Non Performing Loans has no effect on Return On Assets. For simultaneous hypothesis testing (Test F), the results obtained are that the independent variables namely Loan to Deposit Ratio, Capital Adequacy Ratio and Non Performing Loans simultaneously influence the Return on Assets.

Key words : $\quad$ Loan to Deposit Ratio (LDR), Capital Adequacy Ratio (CAR), Non Performing Loan (NPL), Return On Asset (ROA).
Banking Profitability

Listed on IDX

Submitted: MARET 2021

Accepted: JUNI 2021

\begin{abstract}
ABSTRAK
Penelitian ini bertujuan untuk mengetahui bagaimana pengaruh Loan to Deposit Ratio, Capital Adequacy Ratio dan Non Performing Loan Terhadap Profitabilitas Perbankan Yang Terdaftar di Bursa Efek Indonesia (BEI) yang terjadi pada PT Bank Central Asia Tbk, PT Bank Rakyat Indonesia (Persero) Tbk, PT Bank Mandiri (Persero) Tbk, PT Bank CIMB Niaga Tbk, PT Bank Negara Indonesia (Persero) Tbk, PT Bank Tabungan Negara (Persero) pada tahun 2014-2018.

Data yang digunakan pada penelitian ini adalah data kuantitatif dengan sumber data sekunder yang berasal dari laporan keuangan masing-masing bank. Penelitian ini menggunakan metode analisis statistik deskriptif, analisis inferensia, uji asumsi klasik, analisis linear berganda dan koefisien determinasi. Analisis regresi digunakan untuk mengetahui bagaimana pengaruh variabel independen terhadap variabel dependen dengan nilai signifikasi 5 persen. Sedangkan analisis koefisien determinasi digunakan untuk mengetahui hubungan antara variabel independen dan variabel dependen.

Dari uji hipotesis secara parsial (Uji T) yang telah dilakukan oleh penulis diperoleh hasil bahwa Loan to Deposit Ratio berpengaruh terhadap Return On Asset, Capital Adequacy Ratio tidak berpengaruh terhadap Return On Asset dan Non Performing Loan tidak berpengaruh
\end{abstract}

\section{JIMKES}

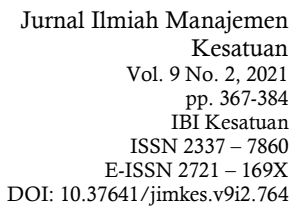


Banking Profitability

Listed on IDX

368 terhadap Return On Asset. Untuk uji hipotesis secara simultan (Uji F) diperoleh hasil bahwa variabel independen yaitu Loan to Deposit Ratio, Capital Adequacy Ratio dan Non Performing Loan berpengaruh secara simultan terhadap Return On Asset.

\section{Kata Kunci : Loan to Deposit Ratio (LDR), Capital Adequacy Ratio (CAR), Non Performing Loan (NPL), Return On Asset (ROA).}

\section{PENDAHULUAN}

Perbankan merupakan suatu lembaga yang memiliki peran penting dalam kegiatan perekonomian yaitu sebagai penghimpun dana masyarakat dan penyalur dana masyarakat. Oleh karena itu, harus ada kehati-hatian dalam menjaga posisi bank serta peran bank agar tidak merugikan kegiatan perekonomian maupun masyarakat. Agar dapat menjalankan fungsinya dengan baik sebagai penghimpun dana masyarakat dan penyalur dana masyarakat maka dibutuhkan bank yang sehat, sehingga bank tersebut dapat menjalankan kegiatan operasionalnya secara optimal. Dalam menciptakan perbanikan yang sehat, maka Bank Indonesia telah mengeluarkan program API yaitu Arsitektur Perbankan Indonesia dimana API ini adalah program penguatan struktur Perbankan Nasional yang bertujuan untuk memperkuat dalam hal permodalan bank sehingga kemampuan bank dalam mengelola resiko menjadi semakin meningkat.

Seperti yang kita ketahui, Bank adalah badan usaha yang menghimpun dana dari masyarakat dalam bentuk simpanan dan menyalurkannya kembali kepada masyarakat dalam bentuk kredit atau dalam bentuk - bentuk lainnya dalam rangka meningkatkan taraf hidup masyarakat. Bank Indonesia melakukan langkah strategis dalam mendorong penerapan manajemen resiko yang tertuang dalam Peraturan Bank Indonesia No.13/1/PBI/2011 tentang Penilaian Tingkat Kesehatan Bank Umum dengan pendekatan resiko yang mencakup penilaian terhadap empat faktor yaitu Risk Profile (Profil Resiko), Good Corporate Govermance (GCG), Earning (Rentabilitas), dan Capital (Permodalan).

Bank dalam menjalankan operasinya tentunya tidak terlepas dari berbagai macam risiko. Risiko usaha Bank merupakan ketidakpastian mengenai suatu hasil yang diperkirakan atau diharapkan akan diterima. Non Performing Loan (NPL) merupakan rasio keuangan yang terkait dengan risiko kredit. NPL adalah perbandingan antara total kredit bermasalah denga total kredit yang diberikan kepada debitur. Bank dikatakan mempunyai NPL yang tinggi jika banyaknya kredit yang bermasalah lebih besar dari pada jumlah kredit yang diberikan kepada debitur. Apabila suatu bank mempunyai NPL yang tinggi, maka akan memperbesar biaya, baik biaya percadangan aktiva produktif maupun biaya lainnya, dengan kata lain semakin tinggi NPL suatu Bank, maka hal tersebut akan mengganggu kinerja Bank tersebut.

Rasio likuiditas merupakan salah satu faktor yang penting dan merupakan rasio yang dapat melihat kemampuan suatu bank dalam melunasi hutang - hutangnya atau kewajibannya. Rasio likuiditas ini tercermin dalam Loan to Deposit Ratio (LDR) merupakan rasio yang mengukur kemampuan Bank untuk memenuhi kewajiban yang harus dipenuhi. Sehingga semakin tinggi LDR maka laba Bank semakin meningkat (dengan asumsi Bank tersebut dapat menyalurkan kreditnya dengan efektif), dengan meningkatnya laba Bank, maka kinerja Bank juga juga meningkat demikian besar kecilnya rasio LDR suatu Bank akan mempengaruhi kinerja Bank tersebut. LDR merupakan rasio untuk melihat kesehatan bank khususnya dalam posisi jangka pendek digunakan untuk menutupi biaya.

Dalam UU No.10 Tahun 1998 terdapat indikator kesehatan bank yang menyebutkan bahwa setiap bank wajib untuk memelihara tingkat kesehatan bank sesuai dengan ketentuan tingkat kecukupan modal. Fungsi permodalan bagi bank yaitu, merupakan sumber utama pembiayaan untuk kegiatan operasional bank itu sendiri, dan juga sebagai penyangga apabila terjadi kemungkinan kerugian dikemudian hari. Selain itu modal juga berfungsi dalam menjaga kepercayaan masyarakat terhadap kemampuan bank tersebut dalam menjalankan 
fungsinya sebagai lembaga intermediasi, sehingga masyarakat tidak ragu untuk menyimpan dananya di bank. Salah satu alat ukur, untuk mengukur pemenuhan kewajiban permodalan adalah dengan menghitung menggunakan rasio CAR (Capital Adequacy Ratio). Dimana rasio CAR ini sebagai tolak ukur untuk menilai tingkat kecukupan modal suatu bank yang bertujuan agar bank tersebut dapat mempertahankan kelangsungan hidupnya dan dapat menjalankan kegiatan operasionalnya dengan optimal. Dengan adanya modal yang tersedia, maka bank akan mampu menyerap kerugian yang timbul di kemudian hari. Bank Indonesia (BI) juga telah menetapkan besarnya rasio CAR yaitu sebesar 8\%. CAR merupakan salah satu variabel yang paling penting bagi Bank Indonesia (BI) dalam hal menjaga tingkat kesehatan bank.

Berdasarkan latar belakang yang telah dikemukakan tersebut di atas dan berbagai macam faktor yang berpengaruh terhadap profitabilitas, maka dalam penyusunan tugas akhir ini penulis mengidentifikasi masalah sebagai berikut:

1. Bagaimana pengaruh Loan to Deposit Ratio (LDR) terhadap profitabilitas Perbankan yang terdaftar di Bursa Efek Indonesia (BEI)

2. Bagaimana pengaruh Capital Adequacy Ratio (CAR) terhadap profitabilitas Perbankan yang terdaftar di Bursa Efek Indonesia (BEI)

3. Bagaimana pengaruh Non Performing Loan (NPL) terhadap profitabilitas Perbankan yang terdaftar di Bursa Efek Indonesia (BEI)

4. Bagaimana pengaruh Loan to Deposit Ratio (LDR), Capital Adequacy Ratio (CAR), dan Non Performing Loan (NPL) terhadap profitabilitas perbankan yang terdaftar di Bursa Efek Indonesia (BEI)

Berdasarkan latar belakang dan identifikasi masalah yang telah diuraikan, maka maksud dari penelitian ini adalah: (1) Untuk menganalisis pengaruh rasio likuiditas yang tercermin dalam Loan to Deposit Ratio (LDR) terhadap Profitabilitas Perbankan yang terdaftar di Bursa Efek Indonesia (BEI). (2) Untuk menganalisis pengaruh Capital Adequacy Ratio (CAR) terhadap Profitabilitas Perbankan yang terdaftar di Bursa Efek Indonesia (BEI). (3) Untuk menganalisis pengaruh rasio kualitas aktiva yang tercermin dalam Non Performing Loan (NPL) terhadap Profitabilitas Perbankan yang terdaftar di Bursa Efek Indonesia (BEI)

\section{Kerangka Pemikiran}

Kerangka pemikiran teoritis merupakan penjabaran teori - teori serta faktor - faktor yang berkaitan dan mempunyai peranan penting dalam penyusunan proposal skripsi. Oleh karena itu penyusunannya harus di dukung dengan landasan teori yang kuat.

Menurut Undang-Undang RI Nomor 10 Tahun 1998 tanggal 10 November 1998 tentang Perbankan, yang dimaksud dengan bank adalah badan usaha yang menghimpun dana dari masyarakat dalam bentuk simpanan dan menyalurkannya kepada masyarakat dalam bentuk kredit dan atau bentuk - bentuk lainnya dalam rangka meningkatkan taraf hifup rakyat banyak. Sedangkan pengertian Bank menurut wikipedia, bank adalah sebuah lembaga intermediasi keuangan umumnya didirikan dengan kewenangan untuk menerima simpanan uang, meminjamkan uang, dan menerbitkan promes atau yang dikenal sebagai banknote. (http://id.wikipedia.org/wiki/bank)

Rasio Profitabilitas, rasio ini menggambarkan kemampuan perusahaan mendapatkan laba melalui semua kemampuan, dan sumber daya yang ada seperti aktiva, modal, atau penjualan perusahaan. Rasio inilah yang akan diukur atau yang akan digunakan penulis dalam menganalisis suatu perusahaan yang berada dalam kondisi sehat ataupun tidak sehat.

Menurut Irfan Fahmi (2014) dalam buku Manajemen Risiko menyatakan bahwa: Suatu pendekatan terstruktur dalam mengelola ketidakpastian yang berkaitan dengan ancaman, suatu rangkaian aktivitas manusia termasuk penilaian resiko, pengembangan strategi untuk mengelola dan mitigasi resiko dengan menggunakan pemberdayaan sumber daya. Manajemen resiko dalam operasional bank meliputi identifikasi risiko, pengukuran dan 
Banking Profitability

Listed on IDX penilaian, dan tujuannya adalah untuk meminimalisir efek negatif risiko terhadap hasil keuangan dan modal bank.

Modal merupakan salah satu faktor penting bagi bank dalam rangka pengembangan usaha dan menampung resiko kerugian. Menurut Wikipedia, modal adalah kewajiban karena membebankan keharusan pembayaran deviden kepada pemilik atau dalam kasus likuidasi pembayaran sisa hasil penjualan aktiva setelah dikurangi pelunasan berbagai kewajiban lain.

\section{METODE PENELITIAN}

Gambaran Objek Penelitian. Gambaran objek penelitian merupakan uraian tentang sejarah pendirian perusahaan, kegiatan usaha perusahaan, struktur organisasi perusahaan serta informasi lain yang ada kaitannya dengan objek yang diteliti.

Oleh karena itu, penulis akan membahas sejarah singkat dari keenam objek penelitian yang diambil yaitu PT Bank Central Asia Tbk., PT Bank Rakyat Indonesia (Persero) Tbk., PT Bank Mandiri (Persero) Tbk., PT Bank CIMB Niaga Tbk., PT Bank Negara Indonesia (Persero) Tbk., dan PT Bank Tabungan Negara (Persero).

Metode Penelitian. Jenis penelitian yang digunakan adalah penelitian kuantitatif. Metode Penelitian yang digunakan dalam penelitian ini adalah metode deskriptif.

Menurut Sukmadinata (2006) Penelitian Deskriptif adalah:

"suatu bentuk penelitian yang ditujukan untuk mendeskripsikan fenomena-fenomena yang ada, baik fenomena alamiah maupun fenomena buatan manusia".

Operasionalisasi Variabel adalah unsur penelitian tentang bagaimana caranya mengukur suatu variabel. Adapun variabel - variabel yang menjadi indikatornya adalah sebagai berikut :

1. Variabel Bebas (Independent Variable)

Variabel bebas adalah variabel yang mempengaruhi variabel lain. Pada penelitian ini yang menjadi variabel bebas adalah :

a. Loan to Deposit Ratio (LDR) (X1)

Adalah rasio untuk mengukur total kredit terhadap total dana pihak ketiga yang disalurkan dalam bentuk kredit.

b. Capital Adequacy Ratio (CAR) (X2)

Adalah rasio kinerja bank untuk mengukur kecukupan modal yang dimiliki bank untuk menunjang aktiva yang mengandung atau menghasilkan resiko, misalnya kredit yang diberikan.

c. Non Performing Loan (NPL) (X3)

Adalah rasio kredit bermasalah dengan total kredit, semakin kecil NPL maka semakin kecil risiko kredit yang ditanggung oleh bank.

2. Variabel Terikat (Dependent Variable)

Variabel terikat adalah variabel yang dapat dipengaruhi oleh variabel lain. Pada penelitian ini yang menjadi variabel terikat adalah profitabilitas yaitu kemampuan suatu bank dalam menghasilkan laba usaha dengan modal sendiri dan modal asing yang dipergunakan untuk menghasilkan laba tersebut.

Jenis dan Sumber Data. Jenis data dalam penelitian ini adalah data kuantitatif. Data kuantitatif adalah jenis data yang dapat diukur (measurable) atau dihitung secara langsung sebagai variabel angka atau bilangan. Sumber data yang digunakan dalam penelitian ini adalah data sekunder.

Populasi dan Sampel. Metode pengumpulan sampel yang digunakan dalam penelitian ini adalah Purposive Sampling. Sampel yang digunakan dalam penelitian ini adalah perusahaan Perbankan Konvensional yang terdaftar di Bursa Efek Indonesia (BEI). Dengan kriteria sampel sebagai berikut:

1. Bank yang dijadikan sampel adalah bank yang terdaftar di Bursa Efek Indonesia (BEI). 
2. Merupakan bank konvensional.

3. Merupakan bank yang termasuk dalam 10 bank terbesar di Indonesia.

Banking Profitability

4. Data laporan keuangan pada periode penelitian tersedia yaitu pada tahun $2012-2016$.

Berdasarkan kriteria tersebut makan bank yang diambil sebagai sampel adalah sebanyak 6 Bank yaitu PT Bank Central Asia Tbk., PT Bank Rakyat Indonesia (Persero) Tbk., PT Bank Mandiri (Persero) Tbk., PT Bank CIMB Niaga Tbk., PT Bank Negara Indonesia (Persero) Tbk., dan PT Bank Tabungan Negara (Persero). Dengan kurun waktu yang diambil oleh peneliti yaitu 5 tahun dari tahun 2012 sampai dengan tahun 2016.

Prosedur Pengumpulan Data. Dalam penelitian ini, penulis memerlukan data dan keterangan-keterangan yang merupakan dasar dalam pembahasan proposal skripsi.

Teknik pengumpulan data yang digunakan dalam penelitian ini adalah:

1. Studi Kepustakaan (Library Research)

Studi kepustakaan dimaksudkan untuk memperoleh data dengan cara mempelajari, meneliti, mengkaji dan menelaah literatur berupa buku, jurnal maupun makalah yang berhubungan dengan penelitian untuk memperoleh bahan-bahan yang akan dijadikan sebagai landasan teori.

2. Riset Internet (Online Research)

Pengumpulan data yang berasal dari situs-situs yang berhubungan dengan berbagai informasi yang dibutuhkan dalam penelitian.

\section{Metode Analisis}

\section{Uji Statistik Deskriptif}

Statistik deskriptif digunakan agar variabel-variabel dalam penelitian ini dapat dideskripsikan. Alat analisis yang digunakan dalam mendeskripsikan penelitian ini adalah rata-rata (mean), standar deviasi, maksimum dan minimum (Ghozali, 2011). Statistik deskriptif menyajikan ukuran-ukuran numerik yang sangat penting bagi data sampel. Uji statistik deskriptif tersebut dilakukan dengan program SPSS.

\section{Analisis Inferensia}

Analisis Inferensia adalah teknik analisis data yang digunakan untuk menentukan sejauh mana kesamaan antara hasil yang diperoleh dari suatu sampel dengan hasil yang akan didapat pada populasi secara keseluruhan. Jadi analisis inferensia akan membantu peneliti untuk mencari tahu apakah hasil yang diperoleh dari suatu sampel dapat digeneralisasi pada populasi.

\section{Uji Asumsi Klasik}

Asumsi klasik yang digunakan dalam penelitian ini meliputi uji normalitas, uji multikolinearitas, uji heteroskedastisitas dan uji autokorelasi. Uji ini dilakukan sebelum dilakukan uji regresi berganda.

\section{Analisis Regresi Linear Berganda}

Menurut Dr. Riduwan dalam bukunya yaitu Dasar-Dasar Statistika (2013), analisis regresi linear berganda merupakan pengembangan dari analisis regresi sederhana. Kegunaannya untuk meramalkan nilai variabel terkait $(\mathrm{Y})$ apabila variabel bebas minimal dua atau lebih. Yang dimaksud dengan Analisis Regresi Linear Berganda adalah alat analisis peramalan nilai pengaruh dua variabel bebas atau lebih terhadap satu variabel terikat untuk membuktikan ada atau tidaknya hubungan fungsional atau hubungan kausal antara dua variabel bebas atau lebih dengan satu variabel terikat.

\section{Koefisien Determinasi $\left(\mathbf{R}^{2}\right)$}

Menurut Dr. Riduwan dalam bukunya yaitu Dasar-Dasar Statistika (2013), analisis koefisien determinasi dapat digunakan untuk mengetahui seberapa erat hubungan antara variabel bebas dengan variabel terikat. Koefisien determinasi akan menjelaskan seberapa besar perubahan atau variasi suatu variabel bisa dijelaskan oleh perubahan atau variasi pada variabel yang lain. 
Banking Profitability

Listed on IDX

372

\section{Uji Hipotesis}

Pengujian hipotesis dalam penelitian ini menggunakan penyajian secara simultan (Uji F) dan pengujian secara parsial (Uji T).

\section{Hipotesis}

Berdasarkan kerangka pemikiran teoritis, rumusan masalah maka dapat dirumuskan hipotesis sebagai berikut:

H1: Diduga rasio Loan to Deposit Ratio (LDR) memiliki pengaruh yang negatif terhadap Profitabilitas.

H2: Diduga rasio Capital Adequacy Ratio (CAR) memiliki pengaruh yang negatif terhadap Profitabilitas.

H3: Diduga rasio Non Performing Loan (NPL) memiliki pengaruh yang negatif terhadap Profitabilitas.

\section{HASIL DAN PEMBAHASAN}

\section{Analisis Data}

Pada bagian ini akan dibahas mengenai analisis data yang telah diperoleh. Data tersebut bersumber dari laporan keuangan yang telah terdaftar di Bursa Efek Indonesia (BEI), sampel yang digunakan dalam penelitian ini yaitu 6 Bank yang terdaftar di Bursa Efek Indonesia (BEI) termasuk bank milik pemerintah dan bank milik swasta nasional. Adapun laporan keuangan yang diteliti yaitu kurun waktu 5 (lima) tahun, dimulai dari periode 2014 sampai dengan 2018 maka observasi yang diperoleh dapat ditentukan sejumlah 30 observasi.

Berikut adalah ringkasan data yang telah diolah dan digunakan dalam penelitian ini:

1. Loan to Deposit Ratio (LDR) tahun 2014-2018 sebagai variabel X1 (dalam persen) yang disajikan pada tabel 1

Tabel 1.Loan to Deposit Ratio (LDR)

\begin{tabular}{|c|c|c|c|c|c|c|}
\hline \multirow{3}{*}{ No } & \multirow{3}{*}{ Nama Bank } & \multicolumn{5}{|c|}{ LDR (X1) } \\
\hline & & $\%$ & $\%$ & $\%$ & $\%$ & $\%$ \\
\hline & & 2014 & 2015 & 2016 & 2017 & 2018 \\
\hline 1 & PT Bank Central Asia Tbk. & 76,08 & 81,01 & 77,01 & 78,02 & 81,60 \\
\hline 2 & $\begin{array}{l}\text { PT Bank Rakyat Indonesia } \\
\text { (Persero) Tbk. }\end{array}$ & 81,68 & 86,88 & 87,77 & 88,13 & 89,57 \\
\hline 3 & $\begin{array}{l}\text { PT Bank Mandiri (Persero) } \\
\text { Tbk. }\end{array}$ & 82,02 & 87,05 & 85,86 & 87,16 & 95,46 \\
\hline 4 & PT Bank CIMB Niaga Tbk. & 99,46 & 97,98 & 98,38 & 96,24 & 97,18 \\
\hline 5 & $\begin{array}{l}\text { PT Bank Negara Indonesia } \\
\text { (Persero) Tbk. }\end{array}$ & 87,08 & 87,08 & 90,04 & 85,06 & 88,08 \\
\hline 6 & $\begin{array}{l}\text { PT Bank Tabungan Negara } \\
\text { (Persero). }\end{array}$ & 108,06 & 108,78 & 102,66 & 103,13 & 103,25 \\
\hline
\end{tabular}

(Sumber : Laporan Keuangan Publikasi Bank) 
2. Capital Adequacy Ratio (CAR) tahun 2014-2018 sebagai variabel X2 (dalam persen) yang disajikan pada tabel 2

Banking Profitability Listed on IDX

Tabel 2. Capital Adequacy Ratio (CAR)

\begin{tabular}{|c|c|c|c|c|c|c|}
\hline \multirow{3}{*}{ No } & \multirow{3}{*}{ Nama Bank } & \multicolumn{5}{|c|}{ CAR (X2) } \\
\hline & & $\%$ & $\%$ & $\%$ & $\%$ & $\%$ \\
\hline & & 2014 & 2015 & 2016 & 2017 & 2018 \\
\hline 1 & $\begin{array}{l}\text { PT Bank Central Asia } \\
\text { Tbk. }\end{array}$ & 16,09 & 18,07 & 21,09 & 23,01 & 23,40 \\
\hline 2 & $\begin{array}{l}\text { PT Bank Rakyat } \\
\text { Indonesia (Persero) Tbk. }\end{array}$ & 18,31 & 20,59 & 22,91 & 22,96 & 21,21 \\
\hline 3 & $\begin{array}{l}\text { PT Bank Mandiri } \\
\text { (Persero) Tbk. }\end{array}$ & 16,60 & 18,60 & 21,36 & 21,64 & 20,96 \\
\hline 4 & PT Bank CIMB Niaga Tbk. & 15,58 & 16,28 & 17,96 & 18,60 & 19,66 \\
\hline 5 & $\begin{array}{l}\text { PT Bank Negara } \\
\text { Indonesia (Persero) Tbk. }\end{array}$ & 16,02 & 19,05 & 19,04 & 18,05 & 18,05 \\
\hline 6 & $\begin{array}{l}\text { PT Bank Tabungan } \\
\text { Negara (Persero). }\end{array}$ & 14,64 & 16,97 & 20,34 & 18,87 & 18,21 \\
\hline
\end{tabular}

(Sumber : Laporan Keuangan Publikasi Bank)

3. Non Performing Loan (NPL) tahun 2014-2018 sebagai variabel X3 (dalam persen) yang disajikan pada tabel 3

Tabel 3. Non Performing Loan (NPL)

\begin{tabular}{|c|c|c|c|c|c|c|}
\hline \multirow{3}{*}{ No } & \multirow{3}{*}{ Nama Bank } & \multicolumn{5}{|c|}{ NPL (X3) } \\
\hline & & $\%$ & $\%$ & $\%$ & $\%$ & $\%$ \\
\hline & & 2014 & 2015 & 2016 & 2017 & 2018 \\
\hline 1 & $\begin{array}{l}\text { PT Bank Central Asia } \\
\text { Tbk. }\end{array}$ & 0,20 & 0,20 & 0,30 & 0,40 & 0,40 \\
\hline 2 & $\begin{array}{l}\text { PT Bank Rakyat } \\
\text { Indonesia (Persero) Tbk. }\end{array}$ & 1,69 & 2,02 & 2,03 & 2,10 & 2,14 \\
\hline 3 & $\begin{array}{l}\text { PT Bank Mandiri } \\
\text { (Persero) Tbk. }\end{array}$ & 0,44 & 0,60 & 1,38 & 1,06 & 0,67 \\
\hline 4 & PT Bank CIMB Niaga Tbk. & 1,94 & 1,59 & 2,16 & 2,16 & 1,55 \\
\hline 5 & $\begin{array}{l}\text { PT Bank Negara } \\
\text { Indonesia (Persero) Tbk. }\end{array}$ & 0,40 & 0,90 & 0,40 & 0,70 & 0,80 \\
\hline 6 & $\begin{array}{l}\text { PT Bank Tabungan } \\
\text { Negara (Persero). }\end{array}$ & 2,76 & 2,11 & 1,85 & 1,66 & 1,83 \\
\hline
\end{tabular}

(Sumber: Laporan Keuangan Publikasi Bank)

4. Return on Asset (ROA) tahun 2014-2018 sebagai variabel Y (dalam persen) yang disajikan pada tabel 4 
Tabel 4. Return on Asset (ROA)

\begin{tabular}{|c|c|c|c|c|c|c|}
\hline \multirow{3}{*}{ No } & \multirow{3}{*}{ Nama Bank } & \multicolumn{5}{|c|}{ ROA (Y) } \\
\hline & & $\%$ & $\%$ & $\%$ & $\%$ & $\%$ \\
\hline & & 2014 & 2015 & 2016 & 2017 & 2018 \\
\hline 1 & $\begin{array}{l}\text { PT Bank Central Asia } \\
\text { Tbk. }\end{array}$ & 3,90 & 3,80 & 4,00 & 3,90 & 4,00 \\
\hline 2 & $\begin{array}{l}\text { PT Bank Rakyat } \\
\text { Indonesia (Persero) Tbk. }\end{array}$ & 4,73 & 4,19 & 3,84 & 3,69 & 3,68 \\
\hline 3 & $\begin{array}{l}\text { PT Bank Mandiri } \\
\text { (Persero) Tbk. }\end{array}$ & 3,57 & 3,15 & 1,95 & 2,72 & 3,17 \\
\hline 4 & PT Bank CIMB Niaga Tbk. & 1,44 & 0,47 & 1,09 & 1,70 & 1,85 \\
\hline 5 & $\begin{array}{l}\text { PT Bank Negara } \\
\text { Indonesia (Persero) Tbk. }\end{array}$ & 3,50 & 2,60 & 2,70 & 2,70 & 2,80 \\
\hline 6 & $\begin{array}{l}\text { PT Bank Tabungan } \\
\text { Negara (Persero). }\end{array}$ & 1,14 & 1,61 & 1,76 & 1,71 & 1,34 \\
\hline
\end{tabular}

(Sumber : Laporan Keuangan Publikasi Bank)

Berdasarkan data tersebut di atas, didapatkan rata-rata rasio keuangan 6 Bank tahun 20142018 dalam presentase yang disajikan pada tabel 5 .

Tabel 5. Rata-Rata Rasio Keuangan 6 Bank Tahun 2014-2018

\begin{tabular}{|c|c|c|c|c|}
\hline \multirow{3}{*}{ Tahun } & \multicolumn{4}{|c|}{ Rasio Keuangan } \\
\cline { 2 - 5 } & LDR & CAR & NPL & \multicolumn{1}{c|}{ ROA } \\
\cline { 2 - 5 } & \% & \% & \% & \% \\
\hline 2014 & 89.42 & 16.37 & 1.23 & 3.04 \\
\hline 2015 & 91.59 & 18.44 & 1.24 & 2.63 \\
\hline 2016 & 90.36 & 20.64 & 1.35 & 2.55 \\
\hline 2017 & 89.74 & 20.61 & 1.35 & 2.73 \\
\hline 2018 & 92.64 & 20.32 & 1.23 & 2.80 \\
\hline
\end{tabular}

Berdasarkan tabel di atas dapat disimpulkan bahwa:

1. Rata-rata LDR pada 6 bank di Indonesia tahun 2014-2018 mengalami fluktuasi, dimana terjadi kenaikan pada tahun 2015 dengan rata-rata LDR pada tahun sebelumnya yaitu 2014 sebesar $89.42 \%$ menjadi $91.59 \%$, namun terjadi penurunan pada tahun 2016 dengan rata-rata LDR sebesar $90.36 \%$, pada tahun 2017 terjadi kembali penurunan yaitu rata-rata LDR sebesar $89.74 \%$, dan terjadi kenaikan pada tahun 2018 dengan rata-rata LDR menjadi 92.64\%. Walaupun LDR mengalami fluktuasi akan tetapi LDR masih dalam perkembangan yang baik, dimana sesuai yang disyaratkan Bank Indonesia dimana batas bawah yaitu sebesar $82 \%$ dan batas atas sebesar 94\%. LDR yang mempunyai nilai yang besar, maka menunjukkan suatu bank tersebut mengelola dana pihak ketiga untuk disalurkan menjadi kredit agar tidak banyak dana pihak ketiga yang diendapkan.

2. Rata-rata CAR pada 6 bank di Indonesia tahun 2014-2018 mengalami fluktuasi, dimana terjadi kenaikan pada tahun 2015 dengan rata-rata CAR pada tahun sebelumnya yaitu 2014 sebesar $16.37 \%$ menjadi $18.44 \%$, pada tahun 2016 terjadi kembali kenaikan yaitu rata-rata CAR sebesar 20.64\%, namun terjadi penurunan pada tahun 2017 yaitu rata-rata 
CAR sebesar $20.61 \%$, dan pada tahun 2018 terjadi kembali penurunan yaitu rata-rata CAR 20.32\%. Walaupun CAR mengalami fluktuasi akan tetapi CAR masih dalam perkembangan yang baik, dimana sesuai yang disyaratkan Bank Indonesia dimana CAR dikatakan sehat jika presentasenya $>8 \%$.

3. Rata-rata NPL pada 6 bank di Indonesia tahun 2014-2018 mengalami fluktuasi, dimana terjadi kenaikan pada tahun 2015 dengan rata-rata NPL pada tahun sebelumnya yaitu 2014 sebesar $1.23 \%$ menjadi $1.24 \%$, pada tahun 2016 terjadi kembali kenaikan yaitu ratarata NPL sebesar $1.35 \%$, pada tahun 2017 tidak terjadi kenaikan atau penurunan yaitu rata-rata NPL sebesar 1.35\%, namun terjadi penurunan pada tahun 2018 dengan rata-rata NPL sebesar $1.23 \%$. Walaupun setiap tahunnya nilai NPL mengalami fluktuasi, akan tetapi nilai tersebut masih dalam batas aman, sebagaimana yang ditetapkan oleh Bank Indonesia yaitu maksimal sebesar 5\%.

4. Rata-rata ROA pada 6 bank di Indonesia tahun 2014-2018 mengalami fluktuasi, dimana terjadi penurunan pada tahun 2015 dengan rata-rata ROA pada tahun sebelumnya yaitu 2014 sebesar $3.04 \%$ menjadi $2.63 \%$, pada tahun 2016 terjadi kembali penurunan yaitu ratarata ROA sebesar $2.55 \%$, namun terjadi kenaikan pada tahun 2017 dengan rata-rata ROA sebesar 2.73\%, pada tahun 2018 terjadi kembali peningkatan dengan rata-rata ROA sebesar 2.80\%. Walaupun mengalami fluktuasi akan tetapi ROA masih dalam perkembangan yang baik, dimana sesuai Peraturan Bank Indonesia batas aman ROA adalah $1.5 \%$

\section{Pembahasan}

Berdasarkan input data variabel Loan to Deposit Ratio (LDR), Capital Adequacy Ratio (CAR), Non Performing Loan (NPL) dan Return On Asset (ROA) pada tahun 2014 sampai tahun 2018 dengan menggunakan program SPSS 25.0 for windows untuk mempermudah dalam menganalisis data, maka dihasilkan berbagai output pengujian yang digunakan sebagai acuan pembahasan.

\section{Hasil Analisis Deskriptif}

Berdasarkan input data yang sudah dilakukan meliputi variabel LDR, CAR, NPL dan ROA maka nilai minimum, nilai maksimum, rata-rata (mean) dan standar deviasi dari masing-masing variabel penelitian dapat dilihat pada tabel 6 berikut ini:

Tabel 6. Descriptive Statistics

\begin{tabular}{|c|c|c|c|c|c|}
\hline & $\mathrm{N}$ & \multirow{2}{*}{ Mean } & \multirow{2}{*}{ Std. Deviation } & \multirow{2}{*}{ Minimum } & \multirow{2}{*}{ Maximum } \\
\hline & Valid & & & & \\
\hline ROA & 30 & 2,7567 & 1,13818 & 0,47 & 4,73 \\
\hline LDR (X1) & 30 & 90,5920 & 9,11237 & 76,08 & 108,78 \\
\hline CAR (X2) & 30 & 19,1373 & 2,39801 & 14,64 & 23,40 \\
\hline NPL (X3) & 30 & 1,2813 & 0,77002 & 0,20 & 2,76 \\
\hline
\end{tabular}

(Sumber: Output SPSS 25.0 for windows (data diolah))

Berdasarkan data pada tabel 6 di atas maka dapat disimpulkan bahwa data rasio LDR terendah (minimum) adalah sebesar $76,08 \%$ yang berasal dari PT Bank Central Asia, Tbk. periode tahun 2014, hal tersebut menunjukkan bahwa kemampuan PT. Bank Central Asia, Tbk pada tahun 2014 dalam menyalurkan kreditnya masih kurang sehingga didapati nilai LDR paling rendah diantara bank lainnya. Sedangkan rasio LDR tertinggi (maksimum) adalah sebesar $108,78 \%$ berasal dari PT Bank Tabungan Negara (Persero) periode tahun 2015, hal tersebut menunjukkan bahwa tingkat penyaluran kredit di PT Bank Tabungan Negara (Persero) lebih tinggi diantara bank lainnya dan kurang baik karena melebihi batas atas LDR sesuai peraturan dari Bank Indonesia. Dengan hasil data yang diperoleh, dapat dilihat rata-rata (mean) rasio LDR adalah sebesar 90,5920\% maka dapat disimpulkan bahwa 
Banking Profitability

Listed on IDX

376 secara statistik tingkat LDR dari bank umum yang terdaftar di Bursa Efek Indonesia (BEI) tahun 2014 - 2018 berada dalam batas aman yaitu tidak kurang dari standar yang sudah ditetapkan oleh Bank Indonesia sebesar 78\% dan tidak lebih dari 92\%, maka dapat diartikan kredit yang disalurkan masih berimbang dengan jumlah dana pihak ketiga yang dihimpun. Untuk melihat simpangan data dari rasio LDR, maka dapat dilihat dari standar deviasinya yaitu sebesar 9,11237\%, dalam hal ini data LDR dapat dikatakan baik karena nilai standar deviasinya lebih kecil daripada nilai mean-nya.

Data rasio CAR terendah (minimum) adalah sebesar 14,64\% berasal dari bank PT Bank Tabungan Negara (Persero) periode tahun 2014, dan data rasio CAR tertinggi (maksimum) adalah sebesar 23,40\% berasal dari PT Bank Central Asia, Tbk periode tahun 2018. Hal ini menunjukkan bahwa baik PT Bank Tabungan Negara (Persero) maupun PT Bank Central Asia, Tbk sama-sama memiliki rasio kecukupan modal yang baik karena diatas $>8 \%$ sesuai dengan standar kesehatan CAR yang ditetapkan oleh Bank Indonesia. Dengan hasil data yang diperoleh, dapat dilihat rata-rata (mean) rasio CAR adalah sebesar 19,1373\%, maka dapat disimpulkan bahwa secara statistik tingkat CAR dari Bank Umum yang terdaftar di Bursa Efek Indonesia (BEI) tahun 2014 - 2018 memiliki kecukupan modal yang baik. Untuk melihat simpangan data dari rasio CAR, maka dapat dilihat dari standar deviasinya yaitu sebesar 2,39801\%, dalam hal ini data CAR dapat dikatakan baik karena nilai standar deviasinya lebih kecil daripada nilai mean-nya.

Data rasio NPL terendah (minimum) adalah sebesar 0,20\% berasal dari PT Bank Central Asia, Tbk. periode tahun 2014 dan 2015, dan data rasio NPL tertinggi (maksimum) adalah sebesar 2,76\% berasal dari PT Bank Tabungan Negara (Persero) periode tahun 2014. Walaupun PT Bank Tabungan Negara (Persero) memiliki rasio NPL tertinggi, namun hal ini masih di dalam batas aman NPL yang ditetapkan oleh Bank Indonesia, yaitu $<5 \%$. Dengan hasil data yang diperoleh, dapat dilihat rata-rata (mean) rasio NPL adalah sebesar 1,2813\%, maka dapat disimpulkan bahwa secara statistik tingkat NPL dari Bank Umum yang terdaftar di Bursa Efek Indonesia (BEI) tahun 2014 - 2018 memiliki kemampuan manajemen yang baik dalam mengelola kredit bermasalah. Untuk melihat simpangan data dari rasio NPL, maka dapat dilihat dari standar deviasinya yaitu sebesar $0,77002 \%$, dalam hal ini data NPL dapat dikatakan baik karena nilai standar deviasinya lebih kecil daripada nilai mean-nya.

Data rasio ROA terendah (minimum) adalah sebesar $0,47 \%$ berasal dari PT Bank CIMB Niaga, Tbk. periode tahun 2015, hal ini menunjukkan bahwa PT Bank CIMB Niaga, Tbk. mengalami kerugian dan dalam meningkatkan keuntungan adalah yang paling buruk daripada bank lainnya. Sedangkan rasio ROA tertinggi (maksimum) adalah sebesar 4,73\% berasal dari PT Bank Rakyat Indonesia (Persero), Tbk. periode tahun 2014, hal ini menunjukkan bahwa kemampuan PT Bank Rakyat Indonesia (Persero), Tbk. dalam meningkatkan keuntungan adalah yang paling baik daripada bank yang lainnya. Dengan hasil data yang diperoleh, dapat dilihat rata-rata (mean) rasio ROA adalah sebesar 2,7567\%, maka dapat disimpulkan bahwa secara statistik tingkat ROA dari Bank Umum yang terdaftar di Bursa Efek Indonesia (BEI) tahun 2014 -2018 memiliki kemampuan manajemen yang baik dalam menghasilkan keuntungan yang besar karena berada di atas standar yang ditetapkan oleh Bank Indonesia yaitu sebesar 1,5\%. Untuk melihat simpangan data dari rasio ROA, maka dapat dilihat dari standar deviasinya yaitu sebesar $1,13818 \%$, dalam hal ini data ROA dapat dikatakan baik karena nilai standar deviasinya lebih kecil daripada nilai mean-nya.

\section{Analisis Inferensia}

\section{Pengaruh Loan to Deposit Ratio (LDR) terhadap Return On Asset (ROA)}

Loan to Deposit Ratio (LDR) merupakan ukuran likuiditas yang mengukur besarnya dana yang ditempatkan dalam bentuk kredit yang berasal dari dana yang dikumpulkan oleh bank terutama dana yang berasal dari masyarakat. Hasil penelitian Mohammad M, Koswar H \& 
Abdul M (2015) meneliti tentang hubungan LDR dengan ROA dan hasil penelitiannya bahwa LDR berpengaruh positif terhadap ROA.

Loan to Deposit Ratio (LDR) merupakan ukuran kemampuan bank dalam membayar kembali penarikan dana yang dilakukan deposan dengan mengandalkan kredit yang diberikan sebagai sumber likuiditasnya. Besar kecilnya rasio LDR suatu bank akan mempengaruhi profitabilitas bank tersebut. Semakin besar jumlah dana yang disalurkan kepada nasabah dalam bentuk kredit maka jumlah dana yang menganggur akan berkurang dan pendapatan bunga yang diperoleh akan meningkat. Dengan meningkatnya pendapatan, berpengaruh terhadap profitabilitas bank tersebut karena bank mendapatkan keuntungan (laba) dari selisih antara bunga ke pihak ketiga dengan bunga ke penerima dana.

\section{Pengaruh Capital Adequacy Ratio (CAR) terhadap Return On Asset (ROA)}

Rasio Kecukupan Modal yang sering disebut dengan Capital Adequacy Ratio (CAR) mencerminkan kemampuan bank untuk menutupi kerugian dari aktivitas yang dilakukannya dan kemampuan bank dalam mendanai kegiatan operasionalnya. Semakin tinggi CAR berarti semakin tinggi modal sendiri untuk mendanai aktivitas produktif, biaya dana yang rendah akan semakin tinggi meningkatkan ROA bank. Demikian sebaliknya, jika semakin rendah modal yang dimiliki maka akan semakin tinggi biaya dana nya yang menyebabkan ROA bank tersebut semakin rendah.

Pengaruh Non Performing Loan (NPL) terhadap Return On Asset (ROA)

Non Performing Loan (NPL) merupakan salah satu pengukuran dari rasio-rasio usaha bank yang menunjukkan besarnya rasio kredit bermasalah yang ada pada suatu bank. Mohammad M, Koswar H \& Abdul M (2015) dalam penelitiannya menguji pengaruh NPL terhadap ROA, hasil penelitiannya menunjukkan hasil yang negatif signifikan terhadap ROA. Semakin tinggi tingkat kredit bermasalah menunjukkan bahwa bank tidak profesional dalam mengelola kredit yang diberikan dan berdampak pada kerugian bank sehingga profitabilitas bank tersebut juga akan menurun.

\section{Hasil Uji Asumsi Klasik}

Sebelum dilakukan uji hipotesis melalui Uji $\mathrm{F}$ dan Uji $\mathrm{T}$ serta untuk menentukan ketepatan modal, maka perlu dilakukan pengujian atas beberapa asumsi klasik.

\section{Hasil Uji Normalitas}

Uji normalitas ini dilakukan dengan tujuan untuk menguji apakah dalam model regresi, variabel pengganggu, atau residual terdistribusi normal. Apabila residual terdistribusi normal, maka uji-t dinyatakan valid. Uji normalitas yang digunakan adalah One-Sample Kolmogorov-Smirnov Test.

Tabel 7. Hasil Uji Normalitas

One-Sample Kolmogorov-Smirnov Test

\begin{tabular}{|l|l|r|}
\hline \multicolumn{2}{|l|}{} & Unstandardized Residual \\
\hline $\mathrm{N}$ & Mean & 30 \\
\cline { 2 - 3 } Normal Parameters & Std. Deviation & .0000000 \\
\hline \multirow{2}{*}{ Most Extreme Differences } & Absolute & .60743267 \\
\cline { 2 - 3 } & Positive & .078 \\
\cline { 2 - 3 } & Negative & .078 \\
\hline \multicolumn{2}{|l|}{ Test Statistic } & -.075 \\
\hline \multicolumn{2}{|l|}{ Asymp. Sig. (2-tailed) } & .078 \\
\hline
\end{tabular}

a. Test distribution is Normal.

b. Calculated from data.

c. Lilliefors Significance Correction.

d. This is a lower bound of the true significance.

(Sumber: Output SPSS 25.0 for windows (data diolah))
Banking Profitability

Listed on IDX

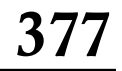


Banking Profitability

Listed on IDX

378
Hasil uji normalitas Kolmogorov-Smirnov pada variabel LDR dan NPL menunjukkan bahwa nilai Asymp. Sig (2 tailed)>-,200. Hal ini menunjukkan bahwa hipotesis nol diterima dan berarti secara keseluruhan variabel berdistribusi normal.

\section{Hasil Uji Multikolinearitas}

Uji Multikolinearitas bertujuan untuk mengukur apakah dalam model ditemukan adanya korelasi antar variabel Independen. Model regresi yang baik seharusnya tidak terjadi korelasi diantara variabel Independen. Pada penelitian ini uji multikolinearitas dilakukan dengan melihat nilai Variance Inflation Factor (VIF) pada model regresi. Apabila variabel memiliki multikolinearitas yang tinggi, maka nilai VIF-nya melebihi nilai 10 (Ghozali, 2009). Tabel 8 menunjukkan hasil uji multikolinearitas yang dimaksud.

Tabel 8. Hasil Uji Multikolinearitas

Coefficients $^{\mathrm{a}}$

\begin{tabular}{|l|l|r|r|}
\hline \multirow{2}{*}{ Model } & \multicolumn{2}{|c|}{ Collinearity Statistics } \\
\cline { 3 - 4 } & (Constant) & Tolerance & \multicolumn{1}{|c|}{ VIF } \\
\cline { 2 - 4 } & LDR (X1) & 0,404 & 2,475 \\
\cline { 2 - 4 } & CAR (X2) & 0,810 & 1,235 \\
\cline { 2 - 4 } & NPL (X3) & 0,460 & 2,173 \\
\hline
\end{tabular}

a. Dependent Variable: ROA (\%)

Berdasarkan hasil uji multikolinearitas di atas bahwa nilai tolerance dari ketiga variabel Independen yaitu LDR, CAR dan NPL berada di atas nilai 0,10 dan VIF ketiga variabel Independen berada di bawah nilai 10. Itu artinya, bahwa tidak ada masalah multikolinearitas antar variabel Independen dalam model regresi.

\section{Hasil Uji Heteroskedastisitas}

Uji heteroskedastisitas bertujuan untuk mengukur apakah ada tidaknya salah satu penyimpangan asumsi klasik, dengan melihat grafik scatterplot antara lain prediksi variabel terikat (dependen) yaitu ZPRED dengan residualnya SRESID, yaitu dengan melihat ada atau tidaknya pola tertentu pada grafik scatterplot antara SRESID dan SPRED dimana sumbu Y adalah Y yang telah diprediksi, dan sumbu X adalah residual (Y prediksi - Y sesungguhnya) yang telah di studentized. Jika ada pola tertentu, seperti titik-titik yang ada membentuk pola tertentu yang teratur (bergelombang, melebar kemudian menyempit) maka mengindikasikan telah terjadi heteroskedastisitas, jika tidak ada pola sumbu Y, maka tidak terjadi heteroskedastisitas (Ghozali, 2009:125-126). Hasil uji heteroskedastisitas berdasarkan grafik scatterplot dapat dilihat pada gambar 1 . 
Gambar 1. Hasil Uji Heteroskedastisitas

Scatterplot

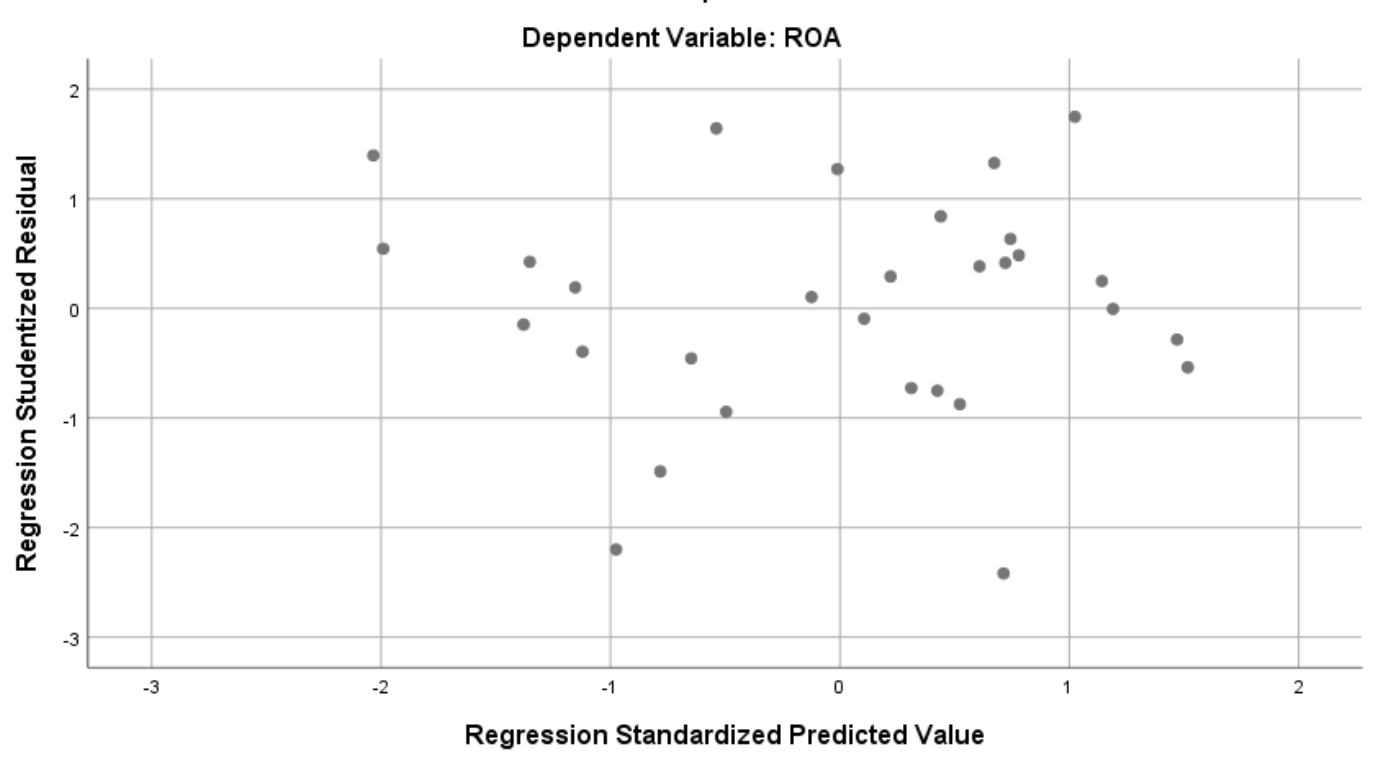

Banking Profitability

Listed on IDX

(Sumber: Output SPSS 25.0 for windows (data diolah))

Pada gambar 1 di atas dapat diketahui bahwa data (titik-titik) menyebar secara merata di atas dan di bawah garis nol, dan tidak berkumpul di suatu tempat, serta tidak membentuk pola tertentu sehingga dapat disimpulkan bahwa pada pengujian ini tidak terjadi masalah heteroskedastisitas.

\section{Hasil Uji Autokorelasi}

Uji autokorelasi bertujuan untuk mengetahui apakah dalam model regresi linier ada korelasi antara kesalahan pengganggu pada periode $t$ dengan kesalahan pengganggu pada periode t-1 (sebelumnya). Uji Durbin-Watson dapat menguji apakah terdapat autokorelasi atau tidak, dengan berdasarkan ketentuan sebagai berikut : jika $2<\mathrm{DW}<+2$ maka tidak ada autokorelasi. Sedangkan jika nilai angka berada pada DW $<-2$ maka terjadi autokorelasi positif, sebaliknya jika nilai angka berada pada $\mathrm{DW}>+2$, maka terjadi autokorelasi negatif.

\section{Tabel 9. Hasil Uji Autokorelasi}

\begin{tabular}{|c|c|}
\multicolumn{2}{|c|}{ Model Summary } \\
\hline Model & Durbin-Watson $^{\mathbf{b}}$ \\
\hline 1 & 1,379 \\
\hline
\end{tabular}

(Sumber: Output SPSS 25.0 for windows (data diolah))

Berdasarkan hasil uji autokorelasi di atas, nilai Durbin-Watson pada Model Summary menunjukkan hasil sebesar 1,379. Karena 1,379 terletak diantara -2 sampai 2 maka dapat disimpulkan bahwa dalam model regresi ini tidak terjadi autokorelasi.

\section{Hasil Koefisien Determinasi $\left(\mathbf{R}^{2}\right)$}

Koefisien determinasi merupakan suatu alat yang digunakan untuk mengukur besarnya persentase pengaruh variabel bebas terhadap variabel terikat. Besarnya koefisien determinasi berkisar antara 0,00 sampai dengan 1,00. Apabila koefisien determinasi semakin mendekati angka 0 , hal itu menunjukkan bahwa garis regresi kurang baik. Sebaliknya, apabila koefisien 
Banking Profitability

Listed on IDX

380 determinasi semakin mendekati angka 1,00, maka garis regresi semakin baik karena mampu menjelaskan data aktualnya (Widarjono, 2009).

Tabel 10. Hasil Koefisien Determinasi $\left(\mathbf{R}^{2}\right)$

Model Summary ${ }^{b}$

\begin{tabular}{|c|c|c|c|c|}
\hline Model & $\mathrm{R}$ & $\mathrm{R}$ Square & Adjusted R Square & $\begin{array}{c}\text { Std. Error of the } \\
\text { Estimate }\end{array}$ \\
\hline 1 & $.846^{\mathrm{a}}$ & .715 & .682 & .642 \\
\hline
\end{tabular}

(Sumber: Output SPSS 25.0 for windows (data diolah))

Pada tabel 10 terlihat Adjusted sebesar 0,682 atau 68,2\% maka LDR, CAR dan NPL memengaruhi ROA sebesar $68,2 \%$ sedangkan sisanya $31,8 \%$ dijelaskan oleh variabel lain di luar model.

\section{Hasil Uji Analisis Regresi Linear Berganda}

Untuk menguji keakuratan hubungan antara ROA (variabel dependen) dengan LDR, CAR dan NPL (variabel independen), dapat dilihat dari tabel berikut:

Tabel 11. Hasil Uji Analisis Regresi Linear Berganda Coefficients $^{\mathrm{a}}$

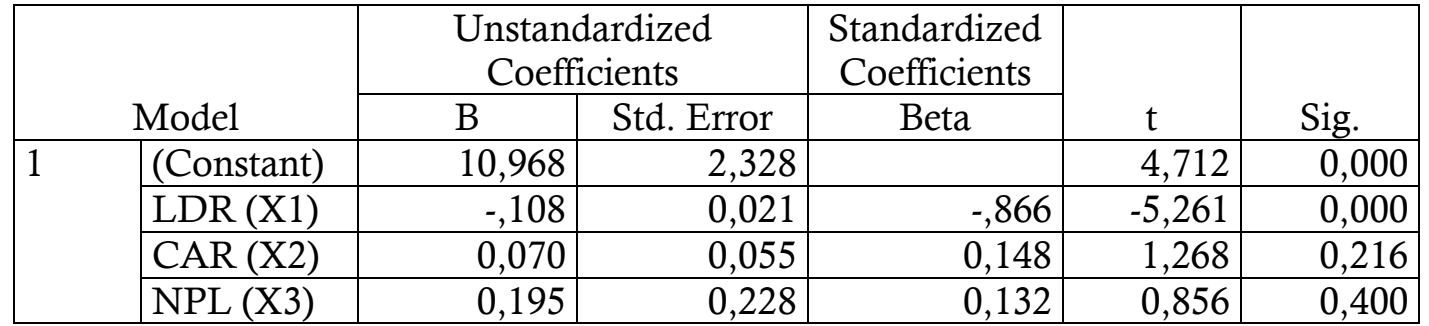

a. Dependent Variable: ROA

(Sumber: Output SPSS 25.0 for windows (data diolah))

Berdasarkan hasil dari coefficients ${ }^{a}$ di atas, maka model hubungan ROA dengan LDR, CAR dan NPL dapat disusun dalam persamaan linear sebagai berikut:

$$
\mathrm{ROA}=10,968-0,108 \mathrm{LDR}+0,070 \mathrm{CAR}+0,195 \mathrm{NPL}
$$

Keterangan :

ROA = nilai imbah hasil aset perusahaan bank yang dianalisis

$\mathrm{LDR}=$ nilai rasio terhadap likuiditas perusahaan bank yang dianalisis

$\mathrm{CAR}=$ nilai rasio kecukupan modal perusahaan bank yang dianalisis

$\mathrm{NPL}=$ nilai rasio bermasalah perusahaan bank yang dianalisis

Berdasarkan model regresi dan tabel 4.11 maka hasil regresi linear berganda dapat dijelaskan sebagai berikut:

1. Persamaan regresi berganda di atas diketahui mempunyai konstanta sebesar 10,968 . Hal ini menunjukkan bahwa jika semua variabel independen diasumsikan sama dengan nol, maka variabel dependen yaitu ROA naik sebesar 10,968\%.

2. Koefisien variabel $L D R=0,108$ dapat diartikan bahwa setiap kenaikan LDR sebesar $1 \%$ akan menyebabkan penurunan ROA $0,108 \%$ (dengan asumsi bahwa variabel bebas lainnya adalah tetap). 
3. Koefisien variabel CAR $=0,070$ dapat diartikan bahwa setiap kenaikan CAR sebesar $1 \%$ akan menyebabkan kenaikan ROA 0,070\% (dengan asumsi bahwa variabel bebas lainnya adalah tetap).

4. Koefisien variabel NPL $=0,195$ dapat diartikan bahwa setiap kenaikan NPL sebesar $1 \%$ akan menyebabakn kenaikan ROA 0,195\% (dengan asumsi bahwa variabel bebas lainnya adalah tetap).

\section{Uji Hipotesis}

Setelah dilakukan pengujian atas beberapa asumsi klasik, maka dapat dilakukan pengujian hipotesis untuk melakukan pengujian terhadap hipotesis-hipotesis yang telah diajukan. Pengujian ini dilakukan untuk menguji hubungan antara varabel dependen yaitu ROA terhadap variabel independen yaitu LDR, CAR dan NPL.

\section{Uji F (Simultan)}

\section{Tabel 12. Uji F (Simultan)}

\begin{tabular}{|c|c|c|c|c|c|c|}
\hline \multicolumn{7}{|c|}{ ANOVA $^{\mathrm{a}}$} \\
\hline \multicolumn{2}{|c|}{ Model } & $\begin{array}{l}\text { Sum of } \\
\text { Squares }\end{array}$ & Df & Mean Square & $\mathrm{F}$ & Sig. \\
\hline \multirow[t]{3}{*}{1} & Regression & 26,868 & 3 & 8,956 & 21,762 &, $000^{\mathrm{b}}$ \\
\hline & Residual & 10,700 & 26 &, 412 & & \\
\hline & Total & 37,568 & 29 & & & \\
\hline
\end{tabular}

a. Dependent Variable: ROA

b. Predictors: (Constant), NPL (X3), CAR (X2), LDR (X1)

(Sumber: Output SPSS 25.0 for windows (data diolah))

Berdasarkan tabel 12 di atas dapat dilihat bahwa hasil uji $\mathrm{F}$ menunjukkan nilai signifikansi sebesar 0,000 dengan nilai F-hitung sebesar 21,762. Nilai signifikansi tersebut lebih kecil daro 0,05 sehingga dapat disimpulkan bahwa variabel independen yaitu LDR, CAR dan NPL berpengaruh secara simultan terhadap ROA sehingga hipotesis yang diajukan diterima.

\section{Uji T (Parsial)}

Uji-t dilakukan untuk menunjukkan pengaruh variabel independen yaitu LDR, CAR dan NPL secara parsial atau individu dalam menerangkan variabel dependen yaitu ROA.

1. Jika tingkat signifikansi lebih besar dari 5\% dapat disimpulkan bahwa Ho diterima, sebaliknya Ha ditolak.

2. Jika tingkat signifikansi lebih kecil dari 5\% dapat disimpulkan bahwa Ho ditolak, sebaliknya Ha diterima.

\section{Tabel 13. Uji T (Parsial)}

Coefficients $^{\mathrm{a}}$

\begin{tabular}{|l|l|r|r|r|r|r|}
\hline \multicolumn{2}{|c|}{} & \multicolumn{2}{|c|}{$\begin{array}{c}\text { Unstandardized } \\
\text { Coefficients }\end{array}$} & $\begin{array}{c}\text { Standardized } \\
\text { Coefficients }\end{array}$ & & \\
\cline { 3 - 5 } \multicolumn{2}{|l|}{ Model } & \multicolumn{1}{|c|}{ B } & Std. Error & Beta & \multicolumn{1}{c|}{ t } & \multicolumn{1}{c|}{ Sig. } \\
\hline \multirow{3}{*}{1} & (Constant) & 10,968 & 2,328 & & 4,712 &, 000 \\
\cline { 2 - 7 } & LDR (X1)(\%) &,- 108 &, 021 &,- 866 & $-5,261$ &, 000 \\
\cline { 2 - 7 } & CAR (X2)(\%) &, 070 &, 055 &, 148 & 1,268 &, 216 \\
\cline { 2 - 7 } & NPL (X3)(\%) &, 195 &, 228 &, 132 &, 856 &, 400 \\
\hline
\end{tabular}

a. Dependent Variable: ROA (\%)

(Sumber: Output SPSS 25.0 for windows (data diolah)) 
Banking Profitability

Listed on IDX

382

Hasil uji statistik pada tabel 4.13 dapat diartikan sebagai berikut:

1. Uji Hipotesis pertama : Loan to Deposit Ratio (LDR) memiliki pengaruh yang negatif terhadap Return On Asset (ROA).

Berdasarkan perhitungan sebagaimana terlihat pada tabel 4.13, diperoleh nilai koefisien regresi dengan arah negatif sebesar $-0,108$. Hasil estimasi variabel LDR atas t hitung sebesar -5,261 dengan probabilitas (signifikansi) sebesar 0,000. Nilai signifikansi sebesar 0,000 lebih kecil dari 0,05, sehingga dapat diartikan bahwa nilai variabel LDR berpengaruh terhadap ROA. Berdasarkan penjelasan di atas membuktikan bahwa dalam penelitian ini LDR berpengaruh terhadap ROA sehingga hipotesis pertama ditolak.

2. Uji Hipotesis kedua : Capital Adequacy Ratio (CAR) memiliki pengaruh yang negatif terhadap Return On Asset (ROA).

Berdasarkan perhitungan sebagaimana terlihat pada tabel 4.13, diperoleh nilai koefisien regresi dengan arah positif sebesar 0,070 . Hasil estimasi variabel CAR atas t hitung sebesar 1,268 dengan probabilitas (signifikansi) sebesar 0,216. Nilai signifikansi sebesar 0,216 lebih besar dari 0,05 sehingga dapat diartikan bahwa nilai CAR tidak berpengaruh terhadap ROA. Bila dilihat tidak berpengaruhnya CAR terhadap ROA kemungkinan karena bank-bank yang beroperasi pada tahun tersebut sangat menjaga besarnya modal yang dimiliki. Berdasarkan penjelasan di atas membuktikan bahwa dalam penelitian ini CAR tidak berpengaruh terhadap ROA sehingga hipotesis kedua diterima.

3. Uji Hipotesis ketiga : Non Performing Loan (NPL) memiliki pengaruh yang negatif terhadap Return On Asset (ROA).

Berdasarkan perhitungan sebagaimana terlihat pada tabel 4.13, diperoleh nilai koefisien regresi dengan arah positif sebesar 0,195. Hasil estimasi variabel NPL atas thitung sebesar 0,856 dengan probabilitas (signifikansi) sebesar 0,400. Nilai signifikansi sebesar 0,400 lebih besar dari 0,05 sehingga dapat diartikan bahwa nilai NPL tidak berpengaruh terhadap ROA. Berdasarkan penjelasan di atas membuktikan bahwa dalam penelitian ini NPL tidak berpengaruh terhadap ROA sehingga hipotesis ketiga diterima.

\section{PENUTUP}

Berdasarkan hasil analisis data dan pembahasan yang telah dikemukakan di bab sebelumnya, maka diperoleh kesimpulan dari penelitian ini yaitu sebagai berikut:

1. Berdasarkan hasil pengujian hipotesis 1 bahwa Loan to Deposit Ratio (LDR) secara parsial berpengaruh positif, hal ini dibuktikan dengan nilai koefisien regresi dengan arah negatif sebesar -5,261 dan didapatkan nilai signifikan sebesar 0,000 lebih kecil dari toleransi kesalahan $\mathrm{a}=0,05$ itu artinya penelitian ini menerangkan hasil yang berpengaruh sehingga hipotesis pertama ditolak.

2. Berdasarkan hasil pengujian hipotesis 2 bahwa Capital Adequacy Ratio (CAR) secara parsial berpengaruh negatif, hal ini dibuktikan dengan nilai koefisien regresi dengan arah positif sebesar 0,070 dan didapatkan nilai signifikan sebesar 0,216 lebih besar dari toleransi kesalahan $a=0,05$ itu artinya penelitian ini menerangkan hasil yang tidak berpengaruh sehingga hipotesis kedua diterima.

3. Berdasarkan hasil pengujian hipotesis 3 bahwa Non Performing Loan (NPL) secara parsial berpengaruh negatif, hal ini dibuktikan dengan nilai koefisien regresi dengan arah positif sebesar 0,195 dan didapatkan nilai signifikan sebesar 0,400 lebih besar dari toleransi kesalahan $a=0,05$ itu artinya penelitian ini menerangkan hasil yang tidak berpengaruh sehingga hipotesis ketiga diterima. 
DAFTAR PUSTAKA

[1] Andanarini, Dhian. 2012. Analisis Pengaruh Ukuran (Size), Capital Adequacy Ratio (CAR), Pertumbuhan Deposit, Loan To Deposit Rasio (LDR), Terhadap Profitabilitas Perbankan Go Public Di Indonesia. Jurnal Manajemen dan Akuntansi Terapan. Vol 3(2): hal 45-54.

[2] Budisantoso, Totok dan Nuritomo. 2014. Bank dan Lembaga Keuangan lain. Jakarta : Salemba Empat

[3] Bungin, Burhan. 2005. Metode Penelitian Kuantitatif. Jakarta: Kencana Prenada Media Group.

[4] Dendawijaya, Lukman. 2009. Manajemen Perbankan. Jakarta: Ghalia Indonesia.

[5] Fahmi, Irfan. 2014. Manajemen Risiko. Bandung : Alfabeta.

[6] Farhat, Wildan. 2018. Pengaruh CAR, BOPO, NPL, NIM Dan LDR Terhadap Profitabilitas Bank Umum. Jurnal Nominal. Vol 7(1): Hal 126-142.

[7] Haryadi, Sarjono \& Winda, Julianita. 2011. SPSS vs LISREL Sebuah Pengantar Aplikasi untuk Riset. Jakarta: Penerbit Salemba Empat.

[8] Kasmir. 2008. Bank dan Lembaga Keuangan Lainnya. Edisi Revisi 2008. Jakarta: PT. Rajagrafindo Persada.

[9] Kasmir. 2016. Dasar-Dasar Perbankan, Edisi Revisi 2014, Rajawali Pers, Jakarta.

[10] Purhantara, Wahyu. 2010. Metode Penelitian Kuantitatif untuk Bisnis. Yogyakarta: Graha Ilmu

[11] Riduwan, 2013. Dasar-Dasar Statistika, Penerbit Alfabeta, Jakarta.

[12] Setiawan, Budi. 2013. Menganalisa Statistik Bisnis dan Ekonomi dengan SPSS 21. Yogyakarta : BukuBeta.

[13] Sudana, I Made. 2011. Manajemen Keuangan Perusahaan Teori dan Praktik. Jakarta : Erlangga

[14] Wijaya, Tony. 2009. Analisis Data Penelitian Menggunakan SPSS. Yogyakarta: Universitas Atmajaya.

[15] www.ojk.go.id diakses tanggal 16 September 2019

[16] www.bi.go.id diakses tanggal 16 September 2019

[17] http://id.wikipedia.org/wiki/bank diakses tanggal 16 September 2019

[18] https://www.academia.edu/6077378/Statistik II Analisis Korelasi Ganda 1 ANALISIS KORELASI GANDA

[19] https://www.bca.co.id/ diakses tanggal 18 Juni 2020

[20] https://www.bankmandiri.co.id/ diakses tanggal 18 Juni 2020

[21] https://www.cimbniaga.co.id/id/personal/index diakses tanggal 18 Juni 2020

[22] https://bri.co.id/ diakses tanggal 18 Juni 2020

[23] https://www.bni.co.id/id-id/ diakses tanggal 18 Juni 2020

[24] https://www.btn.co.id/ diakses tanggal 18 Juni 2020 